\title{
A MECÂNICA DA INSTABILIDADE DE REGIME NA AMÉRICA LATINA
}

\author{
ADAM PRZEWORSKI \\ TRADUÇÃo DE RENATA BRITTO-PEREIRA
}

\section{RESUMO}

Este artigo aborda estritamente um único enigma: por que os países que tentaram instaurar uma democracia mais cedo a vivenciaram com menor frequência? As dinâmicas de regime são impulsionadas por dois mecanismos: (1) as democracias se tornam mais duráveis à medida que aumenta a renda per capita; e (2) experiências anteriores com a democracia desestabilizam tanto democracias quanto autocracias. Assim, países que experimentam uma democracia com níveis de renda mais baixos vivenciam maior instabilidade de regime. Além disso, até atingirem um limite mínimo de renda, em qualquer momento há uma probabilidade menor de esses países serem democráticos do que a de países que vivenciam uma democracia pela primeira vez quando sua renda é mais elevada. Portanto, paradoxalmente, a resistência das monarquias europeias contra a democracia resultou em democracias mais estáveis do que as que se seguiram a tentativas pós-independência na América Latina.

PALAVRAS-CHAVE: América Latina; democracia; instabilidade de regime.

\section{ABSTRACT}

The paper is narrowly addressed to a single puzzle: How did it happen that countries that attempted to install democracy earlier enjoyed it less frequently? Regime dynamics are driven by two mechanisms: (1) Democracies become more durable as per capita income increases, and (2) Past experiences with democracy destabilize both democracies and autocracies. As a result, countries that experiment with democracy at lower income levels experience more regime instability. Moreover, until they reach some income threshold, at any time such countries are less likely to be democratic than countries that first enter democracy when they have higher incomes. Hence, paradoxically, the resistance of European monarchies against democracy resulted in democracies that were more stable than those following post-independence attempts in Latin America.

KEYWORDS: Latin America, democracy, regime instability.

[1] Texto revisado apresentado no simpósio sobre "Novas Fronteiras de Pesquisa Institucional na América Latina", GIGA Institute of Latin American Studies, Hamburgo, 5-6 de maio de 2008. Agradeço pelos muitos comentários de participantes, bem como de José Antonio Cheibub e Carolina Curvale. Este trabalho foi financiado por uma bolsa da National Science Foundation.

[2] Fernando Limongi foi quem primeiro me chamou a atenção para isso.

\section{INTRODUÇÃO}

Este artigo ${ }^{1}$ trata estritamente de um único enigma: por que os países que tentaram instalar uma democracia mais cedo a vivenciaram com menor frequência?

A motivação para o artigo remonta a Lipset (1960: Tabela II), cuja análise contém duas curiosas peculiaridades ${ }^{2}$. A primeira é que o limite mínimo necessário para sustentar uma democracia é mais baixo para a América Latina do que para a Europa e seus derivados anglo-saxões. As democracias europeias, como mostra Lipset, existiam na faixa de renda per capita entre US $\$ 420$ e US\$ 
1.453, enquanto as latino-americanas apresentavam renda per capita entre US\$112 e US\$346. A faixa de renda das democracias latino-americanas é ainda menor do que a de ditaduras europeias, que vai de US\$128 a US\$ 482. A segunda peculiaridade é que as categorias que Lipset usou para a Europa foram "democracias estáveis" e "ditaduras instáveis", enquanto aquelas usadas para a América Latina foram "democracias instáveis" e "ditaduras estáveis". Lipset nunca comentou sobre esses padrões, mas ele detectou algo real e sistemático.

Agora, a afirmação de que países latino-americanos tentaram a democracia mais cedo e, o que é mais importante, com níveis de desenvolvimento econômico mais baixos que os da Europa e da América do Norte não é original's, mesmo que muitas vezes tal afirmação seja recebida com surpresa entre norte-americanos e europeus etnocêntricos. A primeira parte do artigo fornece algumas provas anedóticas e algumas provas sistemáticas que sustentam essa afirmação. A segunda parte analisa a dinâmica dos regimes políticos. A última parte apresenta algumas explicações e levanta algumas questões ainda não respondidas.

Minha preocupaçãoé principalmente com a "mecânica", e não com as causas subjacentes, que recebem abaixo apenas um tratamento superficial. Em outras palavras, a pergunta é "O que precisa ser verdadeiro para que os regimes políticos apresentem a dinâmica que observamos?", e não "Por que isso é verdadeiro?". Além disso, apesar de os mecanismos gerais explicarem boa parte do padrão de instabilidade de regime observado, nem tudo é mecânico. Assim, o artigo propõe tantas perguntas quanto as que responde: ele deve ser visto como uma tentativa de destacar a agenda de novas pesquisas, e não como uma explicação definitiva.

\section{MOMENTO}

De modo geral, as tentativas de democracia ocorreram na América Latina mais cedo e em níveis mais baixos de desenvolvimento econômico do que na Europa. Até certo ponto, essa localização temporal se deve ao fato de que várias partes da América Latina participaram das eleições de 1809 às Cortes de Cádiz, lançando assim a ideia de instituições representativas no momento em que muitos países europeus estavam envolvidos nas guerras napoleônicas e eleições ainda eram incomuns ${ }^{4}$. Mas uma razão mais geral foi que as guerras de independência da América Latina foram simultaneamente voltadas contra o regime monárquico5, enquanto a maioria dos países europeus vivenciou uma devolução gradual do poder dos monarcas para parlamentos.
[3] Annino (1995: 10) observou que "el caso latinoamericano presenta una extraordinaria precocidad en el contexto internacional [...] Si miramos al espacio euroatlántico en su conjunto es evidente que América Latina se encuentra en una situación de vanguardia". Para uma discussão sobre as primeiras constituições da América Latina, ver Gargarella (2005).

[4] Palacios e Moraga (2003: 147) destacam o impacto das eleições para Cádiz: "Limitadas como fueron, las elecciones de 1809 para elegir representantes americanos a la Junta Central constituyeron un momento central en el nacimiento de sistemas políticos modernos en Iberoamérica".

[5] Enquanto em vários países as primeiras declarações de independência prometiam lealdade a Fernando VII, isso parou de ocorrer depois que o regime monárquico foi restabelecido na Espanha. De acordo com Bahamonde e Martínez (1998:15-16),(1) “el Estado transoceánico tenia mucho más connotaciones señorales que coloniales" $\mathrm{e}$ (2) "El liberalismo sirvió, por lo tanto, de arma revolucionaria para contrarrestar los vacios de poder a ambos lados del Atlántico". 
O governo colonial espanhol era direto e centralizado, oferecendo pouca oportunidade para o autogoverno. A única instituição que implicava um pequeno grau de autogoverno na América espanhola - o cabildo - era um órgão estamental, com cargos que podiam ser comprados e mantidos em perpetuidade (após 1556) e apenas alguns postos eletivos, sujeitos à confirmação pela Coroa e eleitos sob um sufrágio muito restrito. Os poderes fiscais do cabildo eram mínimos. O funcionamento dessas instituições era tão ruim que em 1789 intendentes nomeados pela Coroa assumiram a maioria das suas funções. Resumindo sua evolução, Haring (1947: 165) concluiu que "no fim da era colonial, o cabildo havia praticamente desaparecido". Assim, quando o governo colonial espanhol se desintegrou - e ele entrou em colapso não por causa de algum tipo de pressão pela independência nas Américas, mas por causa dos acontecimentos na Europa-, os conflitos que se seguiram não puderam ser resolvidos dentro de um quadro institucional preexistente.

Os latino-americanos precisaram constituir mais uma vez suas instituições. E estavam atravessando uma terra incógnita. Monarquias, repúblicas com órgãos governantes coletivos predominantemente hereditários, e uma república com uma legislatura eleita e um presidente eleito indiretamente eram as opções conhecidas quando primeiramente o Haiti, em 1804, e em seguida a Venezuela, em 1811, proclamaram sua independência. Em vários países novos a primeira forma de governo era um órgão coletivo que exercia tanto a função legislativa quanto a executiva. Triunviratos governaram a Argentina de 1811 a 1814 e a Venezuela em 1811-1812. Mas o executivo coletivo francês já havia então sido extinto, e a experiência francesa não serviu como uma referência para os fundadores latino-americanos. Já Filadélfia figurava com destaque na mente deles: o intermediário foi o general Francisco Miranda, que participou da guerra da independência dos Estados Unidos e que se tornou a figura central na proclamação da Constituição das Províncias Unidas da Venezuela, em 1811. Também teve destaque a Constituição liberal espanhola de Cádiz, adotada em 1812 , que preservava a monarquia, mas limitava rigorosamente seus poderes.

O desejo de uma solução monárquica surgiu intermitentemente na maioria dos países latino-americanos. Na Assembleia Nacional de Tucumán, na Argentina (1816), o general Belgrano apresentou a ideia de una monarquia temperada, um projeto monárquico com um rei nativo das Américas - um monarca de ascendência inca e não de linhagem europeia. O general San Martín também era a favor de uma solução monárquica (López-Alves, 2000: 179). E havia o desejo de uma monarquia sob um príncipe italiano ou britânico no Uruguai. Mas, no fim, apenas o Brasil adotou essa solução até se tornar uma república, 
em 1889. No México o primeiro imperador,Agustín de Iturbide, durou dois anos, e houve um breve retorno à monarquia entre 1862 e 1867. Os motivos pelos quais projetos monárquicos fracassaram, de acordo com Rippy (1965:89), foram que

as realezas da Europa e os monarquistas da América tinham dificuldade de chegar a um acordo, os Estados Unidos se opunham a reis americanos, os príncipes eram dificeis de encontrar, e as pessoas não estavam dispostas a tolerá-los.

No fim, prevaleceram instituições baseadas no padrão dos Estados Unidos - com o tempo, todos os sistemas políticos latino-americanos elegeriam legislaturas e poriam a função executiva nas mãos de presidentes ${ }^{6}$-, mas essa alternativa se tornou complicada desde o princípio devido à ânsia de Bolívar de ocupar o cargo pelo resto da vida. Embora El Libertador não ousasse reivindicar realeza, fez saber a todos que seu ideal era a monarquia constitucional inglesa e que estava ávido por se tornar um monarca pelo resto da vida, ainda que sob o título de presidente (Discurso de Angostura 1819, em Bolívar, 1969)7. A ambição monárquica de Bolívar instaurou nos latino-americanos um medo que só diminuiria no final do século $\mathrm{XX}$ e que se institucionalizou em limites de mandato, o "nó górdio" da política latino-americana (De Luca, 1998:155). Apenas uma Constituição, de autoria do próprio Bolívar, e que durou apenas dois anos a partir de 1826 na Bolívia e ainda menos no Peru, concedia um mandato vitalício ao presidente.

Apesar de essas duas soluções - a monarquia e a república presidencial - serem fundamentais, elas não excluíam a inventividade. O plano para um governo provisório elaborado por Francisco Miranda na década de 1790 estabelecia um executivo eleito pelo parlamento (la Dieta), cujo título teria sido el Inca (Palacios e Moraga, 2003: 102). Os dois primeiros líderes do Chile assumiram o título de "Diretor Supremo da Nação", embora a partir de então tenham passado a ser presidentes. O primeiro título de Miranda foi "Generalissimo". O mais criativo foi o dr. José Gaspar Rodríguez de Francia, que, tendo se tornado, em 1813, um dos dois cônsules que deveriam se alternar no cargo a cada quatro meses, e em seguida nomeado ditador por três anos, em 1816 proclamou-se El Dictador Perpetuo do Paraguai e governou até 1840 como El Supremo ${ }^{8}$. Embora essa história possa parecer uma anedota, a inovação de Francia foi ao mesmo tempo radical e durável, merecendo ser posta em pé de igualdade com a invenção de Lenin do Estado de partido único. Foi uma inovação radical, já que o único modelo de ditadura conhecido na época era o romano, e nesse modelo a ditadura era
[6] O próprio termo tem raízes fracas na tradição colonial espanhola. "La Presidencia" era uma unidade administrativa abaixo da Vice-Realeza e era comandada por um presidente que, como membro daAudiencia, possuía poderes jurisdicionais.

[7] Esse é um texto fascinante. Tendo observado que só a democracia é compatível com a liberdade, Bolivar pergunta qual o governo que melhor conseguiu reunir poder, prosperidade e estabilidade. Sua resposta é "a Inglaterra". Embora admirasse as realizações dos Estados Unidos, ele argumenta que tal experiência não pode ser replicada em outros lugares. Por outro lado, o modelo a ser imitado é o da Grã-Bretanha, uma República de fato. (Isso veio depois que ele argumentou contra seguir o exemplo dos EUA ao invocar Montesquieu no sentido de que as instituições devem refletir as condições locais.) Ele então está pronto para fazer o seu lance: Vocês terão um Senado hereditário, a ser eleito pelo Congresso atual entre vocês, a quem a República deve sua existência, e eu me tornarei o monarca hereditário britânico sob o título de presidente.

[8] Francia é protagonista de um romance histórico ricamente documentado de autoria de Augusto Roa Bastos, Yo el Supremo. No entanto, não consegui achar nele nenhuma expressão de surpresa ante a noção de um ditador perpétuo.As únicas descrições estrangeiras de seu reinado foram feitas por dois naturalistas e um comerciante. Não li nenhuma delas. 
[9] Em Roma, um ditador era nomeado pelo Senado por um tempo limitado para lidar com uma emergência. Quando Bolívar quis renunciar à primeira de suas três ditaduras, por exemplo, ele foi convidado a permanecer no cargo nos seguintes termos: "Permaneça, vossa Excelência, como um Ditador, melhore seus esforços para salvar a Pátria e, uma vez que o tenha feito, em seguida, restaure o pleno exercício da soberania propondo um Governo Democrático". Sobre Bolívar e ditaduras, ver Aguilar (2000: capítuloV).
[10] Bolívar, no discurso em que aceitou o cargo de Dictador Jefe Supremo de la República, já anunciava que "ya respiro devolviéndos esta autoridad" (Discurso de Angostura, em Bolívar, 1969: 93). um poder delegado, excepcional, e limitado em sua duração. "Ditador Perpétuo" era um oximoro9. Além disso, a última tentativa de tornar a ditadura permanente, quase vinte séculos antes, não era um bom presságio para o destino do dr. Francia. No entanto, essa invenção acabou se revelando duradoura: Francia abriu um precedente para cavalheiros ilustres como Mussolini, Hitler, Franco, Kim Il-sung, al-Kadafi, ou Castro.

Portanto, enquanto as ideias liberais se originaram na Europa, os países latino-americanos construíram instituições representativas em grande parte por falta de melhor alternativa: alguma estrutura institucional precisava ser criada para substituir o governo espanhol que havia desmoronado, o monarquismo mostrou-se impraticável e o sucesso do governo republicano nos Estados Unidos oferecia uma solução viável.

Agora, uma objeção à afirmação sobre a precocidade das tentativas democráticas na América Latina é a experiência do caudillismo. Mas, apesar de haver um número sem fim de volumes sobre o tema, esseé um conceito preguiçoso. Embora seja verdade que muitos "generais" atravessaram selvas exóticas para tentar conquistar o poder nas capitais, enquanto outros se afastavam das capitais para tentar conquistar o poder em suas províncias, o aspecto impressionante do governo autocrático na América Latina é que o despotismo foi quase sempre desculpado como excepcional e quase sempre vestido em trajes constitucionais. Como Rippy (1965:93) observou,

Seja de forma sincera, seja de forma deliberadamente enganosa, as expressões empregadas nos documentos da época sempre sugeriam uma crise: libertador, restaurador, regenerador, vindicador, liberador, salvador do país, e assim pordiante. Alguém estava constantemente tendo de "salvar" esses países...

Além disso, citando Paz (1963:3-4),

É significativo que a frequência dos golpes militares nunca tenha esmaecido a legitimidade democrática da consciência do nosso povo. Por esse motivo, os ditadores que assumiam o poder quase invariavelmente declaravam que seu governo era provisório e que estavam prontos para restaurar as instituições democráticas assim que as circunstâncias permitissem ${ }^{10}$.

Ainda mais impressionante é a obsessão da América Latina com o constitucionalismo: a primeira coisa que muitos "caudillos", "homens fortes", "ditadores" ou "autocratas" faziam no palácio presidencial era promulgar uma nova Constituição.

Isso não quer dizer que os generais invadiam palácios presidenciais para depois deixá-los porque alguém havia conseguido mais 
votos. Como Halperin-Donghi (1973: 116) observou com aspereza, "Entre as muitas maneiras de derrubar um governo praticadas na América espanhola pós-revolucionária, a derrota nas urnas estava conspicuamente ausente". Mas, na maior parte do tempo, eles realizavam eleições e mantinham a legislatura aberta. Tinham até a tendência de permitir que alguém disputasse eleições contra eles - eleições sem oposição são um fenômeno mais recente. E talvez o mais peculiar é que eles quase sempre respeitavam os limites de mandato. Seguindo o Chile após 1831 (sobre o qual ver Valenzuela, 1995), vários países latino-americanos estabeleceram sistemas estáveis de sucessão em que os presidentes em exercício concluíam seu mandato, obedecendo fielmente aos limites deste, escolhiam seus sucessores e usavam o poder do governo para garantir sua vitória nas urnas ${ }^{11}$. A estabilidade de tais sistemas - o Chile entre 1831 e 1871, a Nicarágua entre 1856 e 1890 , o Brasil entre 1894 e 1930, a Argentina entre 1897 e 1916, o Uruguai entre 1898 e 1932, o México entre 1934 e 2000 - foi notável.

Agora, um mundo em que os incumbentes, que muitas vezes assumiam o poder através da força, só realizavam eleições se fossem assegurados de que ganhariam não soa muito como uma "democracia". Não estou afirmando que era. Mas naquela época o governo representativo não era uma "democracia" como a definiríamos hojeem dia, nem era visto como tal por seus fundadores na Inglaterra, Suécia, Estados Unidos, França, ou Espanha (Manin, 1997; Dunn, 2005; Hansen, 2005).Aúnica justificativa para usar a linguagem da democracia é genealógica: eleições, legislaturas e o reconhecimento do direito de oposição a governos (pelo menos nas eleições) foram os elementos com os quais as democracias modernas foram subsequentemente feitas. Comparemos, portanto, esses ancestrais da democracia - sufrágio, eleições, oposição - nos diferentes continentes.

Em todos os países, as eleições eram administradas pelos governos incumbentes, e seus resultados eram certificados pelos que eram eleitos dessa maneira (Lehoucq, 2007). Em consequência, intimidações, manipulações e fraudes eram generalizadas. O uso da fraude na América Latina foi amplamente documentado (Annino, 1996; Posada-Carbó, 2000; Lehoucq e Molina, 2002). Mas eleições fora da América Latina também eram caracterizadas por um uso descarado do poder do governo para fins partidários. Foi esse o caso, mesmo que sem sucesso, nos Estados Unidos entre 1796 e 1800 (Dunn, 2004; Weisberger, 2000). Na França, a ideia de uma lista oficial do governo apresentada aos eleitores para uma aprovação plebiscitária existia já sob o Diretório, foi usada durante a Restauração e aperfeiçoada sob Napoleão III (Zeldin, 1958). E a monarquia espanhola ganhou dessa forma tanto controle sobre os eleitores que, entre 1876 e 1917, conseguiu orquestrar um sistema em que os governos se alternavam a cada

\begin{abstract}
[11] Collier e Sater (1996:58) relatam que "A entrega dos votos era um aspecto vital do trabalho do Intendente [equivalente ao prefeito francês] [...] No entanto, às vezes os Intendentes iam longe demais [...] Quando o jovem Intendente de Colchagua, Domingo Santa Maria [futuro presidente], interpretou as instruções do presidente para ganhar as eleições "a todo custo" com um entusiasmo um pouco exagerado, seus inimigos aproveitaram o episódio como pretexto para a demissão dele".
\end{abstract}


eleição de acordo com um acordo pré-arranjado entre os partidos. Garrido (1998:218) relata que

O eleitorado não elegia o Parlamento e não elegia o governo. O sistema funcionava "de cima para baixo": o rei nomeava seu chefe de governo, que convocava eleições, as quais tinham, necessariamente, de conferir uma grande maioria a seu partido.

Da mesma forma, em Portugal, entre 1851 e 1869 ,

As eleições geralmente ocorriam após uma mudança de governo, não antes, e eram então vencidas pelo novo governo, que manipulava a influência dos chefes de partido entre os eleitores das provincias (Birmingham, 1993:132).

Promover candidatos do governo não era uma transgressão, mas sim um dever dos funcionários públicos: o primeiro-ministro francês, Jean-Baptiste de Villèle, emitiu em 1822 uma circular segundo a qual

Todos aqueles que são membros do meu ministério, para manter seus empregos, devem contribuir dentro dos limites do seu direito para a eleição de membros do parlamento sinceramente ligados ao governo (citado em Zeldin, 1958:79).

Portanto, a derrota nas urnas também estava conspicuamente ausente na Europa. Mesmo no caso improvável de incumbentes perderem as eleições, eles não se mostravam ansiosos para ceder o poder. $\mathrm{Na}$ Costa Rica, quando o presidente Braulio Carrillo não conseguiu ser reeleito em 1837, ele derrubou o vencedor das eleições e promulgou uma Constituição que o declarava presidente vitalício, só para ser deposto cinco anos depois. Em Honduras, em 1924, o presidente em fim de mandato Rafael López Gutiérrez declarou-se ditador, impedindo que o vencedor por maioria simples, Tiburicio Carías Andino, assumisse o cargo. Seguiu-se uma guerra civil e Carías depôs López. Mas, novamente, há muitas histórias semelhantes na Europa. Quando o

[12] Antes das eleições de 1866, o governo holandês induziu o rei a fazer uma proclamação exortando os eleitores a escolher representantes que concordassem com o governo. A proclamação foi enviada aos eleitores junto com as cédulas (Block, 1970: 482). O resultado foi uma derrota por pequena margem dos liberais. governo monarquista de Montignac caiu, em maio de 1829, Carlos X dissolveu a Chambre e nomeou um primeiro-ministro interino, o qual fez a ameaça de que, caso a oposição vencesse, o rei seria obrigado a governar por decreto:

Cabe aos eleitores, portanto, agir de modo que a maioria da nova Chambre não seja tal que o rei seria obrigado [...] a tomar medidas fortes... ${ }^{12}$

Na eleição seguinte, a oposição conquistou 274 lugares contra 145 para o ministério. O rei decidiu governar por decreto, novamente dis- 
solveu a Chambre e anunciou novas eleições. Foi deposto por uma revolução. E Carlos X não estava sozinho. Na Bulgária, quando os liberais venceram a primeira eleição, em 1879, o príncipe Alexander dissolveu a assembleia em 1880 . Uma segunda eleição, em 1880, foi novamente vencida pelos liberais. Em 1881, Alexander suspendeu a Constituição, só para ser forçado a abdicar cinco anos depois. O rei Carlos de Portugal teve ainda menos sorte. Em 1907, ele impôs seu primeiro-ministro contra maioria do parlamento. Foi assassinado, em 1908, e a monarquia foi abolida, em 1910.

Nem todos os governantes que se recusaram a respeitar os resultados de eleições foram depostos: incumbentes anularam o resultado de eleições em que eles ou seus sucessores escolhidos a dedo foram derrotados e sobreviveram por pelo menos um mandato no Equador em 1867 e 1869, na Costa Rica em 1906, na Bolívia em 1925, no Peru em 1855 e 1933, em Honduras em 1954, e no Panamá em 1990. Mas também na Europa muitas vezes várias derrotas eleitorais eram necessárias antes de a composição do governo finalmente refletir a maioria eleitoral. Na Inglaterra, o rei nomeou um primeiro-ministro do Partido Conservador apesar de uma derrota eleitoral em 1834, e somente vitórias repetidas da oposição o forçaram a aceitar o governo Melbourne e o próprio princípio de responsabilidade parlamentar. Na Bélgica, os liberais precisaram vencer duas vezes antes de assumir o cargo, em 1847; na Dinamarca, governos minoritários de direita permaneceram no poder apesar de repetidas derrotas entre 1872 e 1901; nos Países Baixos, o mesmo aconteceu entre 1856 e 1871 . Enquanto a primeira alternância partidária de governo resultou na realização de eleições nos Estados Unidos, em 1800 , casos isolados de alternâncias ocorreram na Colômbia, em $1837^{13}$ e 1849, na Nicarágua, em 1847 (por um acordo partidário), em Honduras, em 1852, na República Dominicana, em 1853, e na Argentina, em 1868. Isso não se repetiria tão cedo em lugar algum: nos Estados Unidos em 1829, na Colômbia somente em 1930, na Nicarágua em 1990, em Honduras em 1928, na República Dominicana em 1978 e na Argentina em 1916 (e novamente apenas em 1989). O princípio de que o governo deve se abster de manipular eleições de forma excessiva, não fazer uso extensivo de fraude e ceder se perder só obteve aceitação no Reino Unido em 1834, nos Estados Unidos na década de 1830 (Hofstadter, 1969), na Bélgica depois de 1847, mas também no Chile depois de 1871.

Já que não faltam histórias, precisamos de fatos mais sistemáticos. Primeiro, considere o momento em que os eventos específicos ocorreram, tendo em mente que o último país da América Latina se tornou independente apenas em 1825. A Figura 1 mostra que durante muito tempo eleições ocorriam com maior frequência na América Latina.
[13] Bushnell (1993: 90) descreve assim os eventos: "A eleição [...] em 1837, destaca-se no contexto mais amplo da América Latina do século XIX pelo simples fato de que o candidato favorecido pelo governo que saía foi derrotado e sua derrota foi aceita pacificamente". A escolha do próprio Santander havia sido José María Obando. Santander acreditava que Nova Granada ainda não estava pronta para um presidente civil, razão pela qual ele se opunha ao vencedor final, dr. José Ignacio de Márquez. Márquez recebeu um apoio esmagador da facção bolivariana. Ele ganhou a maioria simples de votos eleitorais e o Congresso confirmou sua vitória. "Santander então entregou seu cargo a alguém a quem ele havia se opostofazendo questão de salientar, em uma proclamação, que ele havia, assim, respeitado a vontade do povo e o direito nacional." O presidente eleito cumpriu até o fim seu mandato. 
FIGURA I

Proporção de países que realizavam eleições, por ano

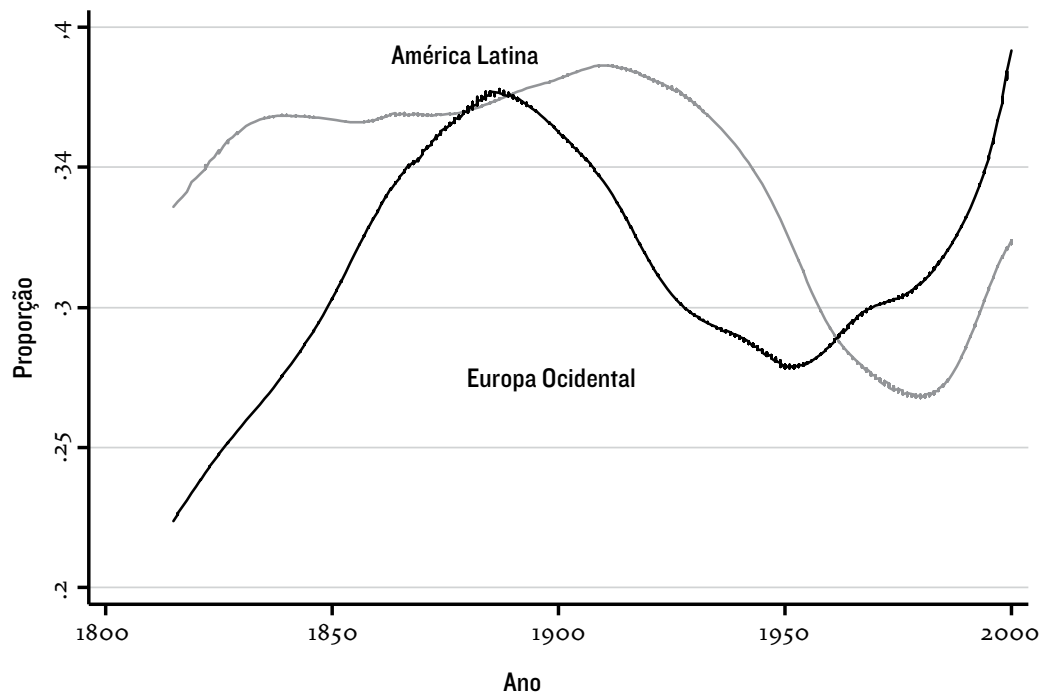

Lowess smooth. As eleições incluem as legislativas e as presidenciais, mas somente uma delas por ano.

Fonte: dados próprios.

[14] De acordo com Sabato (2003: 8), "Lejos de producirse un proceso gradual [...], en buena parte de Iberoamérica la independencia introdujo un concepto relativamente amplio de ciudadano".

[15] O termo equivalente no começo da história norte-americana era "habitante", definido em Nova Jersey em 1766 como um "Freeholder, Tenant for years, or Householder in Township or Precinct" [dono de terras livres de gravames, inquilino há anos ou dono de imóvel no município ou distrito] (Klinghofer e Elkis, 1992: 190n).

[16] No original: "Tener una propiedad, o ejercer cualquiera profesión, o arte con título público, u ocuparse en alguna industria útil, sin sujeción a otro en clase de sirviente o jornalero" (Peru). "Son ciudadanos todos los habitantes de la República naturales del país, o naturalizados en él, que fueren casados, o mayores de diez y ocho años, siempre que ejerzan alguna profesiónútil o tengan medios conocidos de subsistencia" (Costa Rica).

A Figura 2 mostra a localização temporal de diferentes regras de direito de voto. Repare especificamente que, embora o sufrágio universal masculino (categoria 7) tenha sido adotado mais ou menos na mesma época na Europa Ocidental e na América Latina, esse último continente foi o primeiro dos dois a conceder o direito de voto a todos os homens "independentes" (categoria 6)14. A categoria operante que qualificava alguém para o sufrágio na América espanhola era vecino (literalmente, vizinho): alguém que possuía uma fonte regular de renda, tinha residência permanente em uma comunidade e não era dependente de outros ${ }^{15}$. Como vários ensaios incluídos em Sabato (2003) destacam, esse era um conceito sociológico, não jurídico: um vecino era simplesmente alguém com uma posição em uma comunidade local. Além disso, embora as primeiras constituições tentassem definir esse conceito por frases como "Que tenha uma propriedade, ou exerça alguma profissão, ou uma habilidade com um título público, ou tenha uma ocupação de alguma utilidade, sem estar sujeito a outro como criado ou diarista" (Peru em 1823), ou "que exerça alguma ocupação útil ou tenha meios conhecidos de subsistência" (Costa Rica em 1824) ${ }^{16}$, uma vez que a elegibilidade era determinada pelas autoridades locais, a aplicação desses critérios era informal e permissiva. Como Canedo (1998:188-9) conta, se Pedro era conhecido por membros da mesa eleitoral local por ser uma boa pessoa, ele era um vecino. Nesses países, a nacionalização da cidadania (sobre isso, ver Annino, 1995, 1998), que a transformou de um conceito social em um 
conceito jurídico, significava substituir esses critérios vagos por limites mínimos específicos de renda ou de impostos, às vezes em conjunto com a exigência de alfabetização, o que era mais restritivo. Assim, dos dezoito países em que as primeiras qualificações deram o direito de voto a todos os homens "independentes", em quinze deles o sufrágio foi em seguida restringido.

\section{FIGURA 2}

Anos em que determinadas regras de direito de voto estavam em vigor
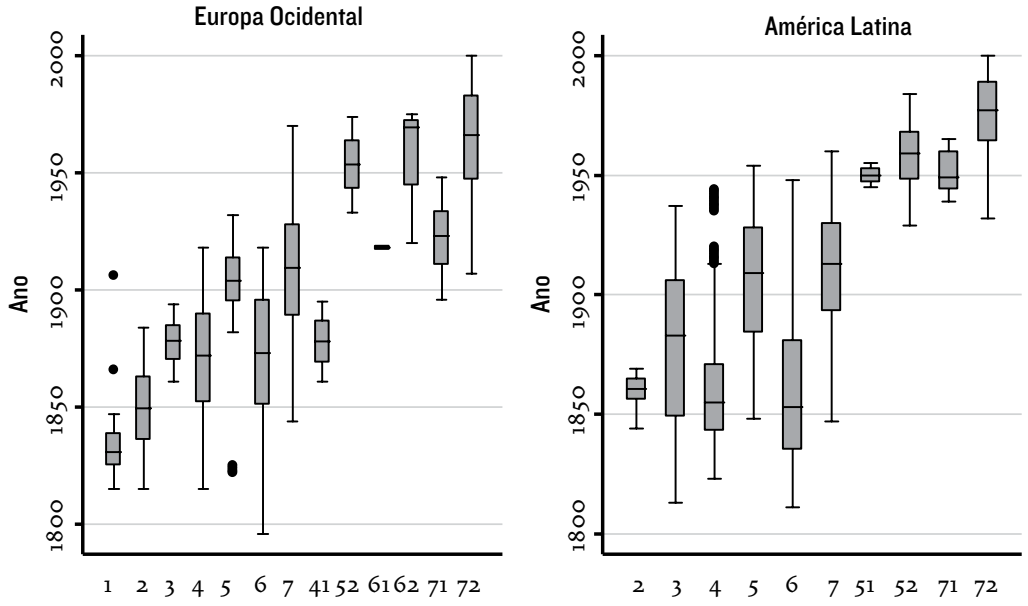

Categorias de direito de voto:

Para homens: 1 parlamento estamental 2 só propriedade imobiliária 3 renda e alfabetização

4 renda ou alfabetização 5 alfabetização 6 dependentes 7 universal

As mulheres estão codificadas pelo segundo dígito: 1 se de forma mais restrita 2 se da mesma forma

Fonte: dados próprios.

A consequência dessas regras, conforme aplicadas de acordo com os contextos econômicos e educacionais, era a proporção da população à qual era concedido o direito de voto, mostrada na Figura 3. Embora possa parecer que a elegibilidade era mais ampla na Europa, esse resultado se deve ao fato de que a série da Europa inclui todos os que eram elegíveis para votar segundo os critérios de direito de voto, enquanto a série da América Latina mistura os números de pessoas elegíveis e eleitores registrados, e essa diferença produz um viés (ver Przeworski, 2009). A correção desse viés geraria séries que seriam quase idênticas.
Nota: esta figura deve ser lida da seguinte forma: (1) a linha horizontal indica o ano mediano, (2) a área na caixa à direita contém $75 \%$ das observações, (3) as linhas que terminam com linhas horizontais contêm $95 \%$ das observações e (4) pontos isolados são casos discrepantes. 
Nota: a. Médias ponderadas de população para países sobre os quais existem dados disponíveis: 17 países em 1820 (excluindo Cuba e República Dominicana) Brasil, México, Argentina, Uruguai e Venezuela em 1870, 13 países em 1930, 18 em 200o.b. Média não ponderada de 12 países em 1820 , 14 em 1870, 15 em 1930 e 19 em 2000. Fonte: Conjunto de dados em Maddison (2003: 114) e Maddison (2003).
Figura 3

Proporção da população elegível para votar, por ano

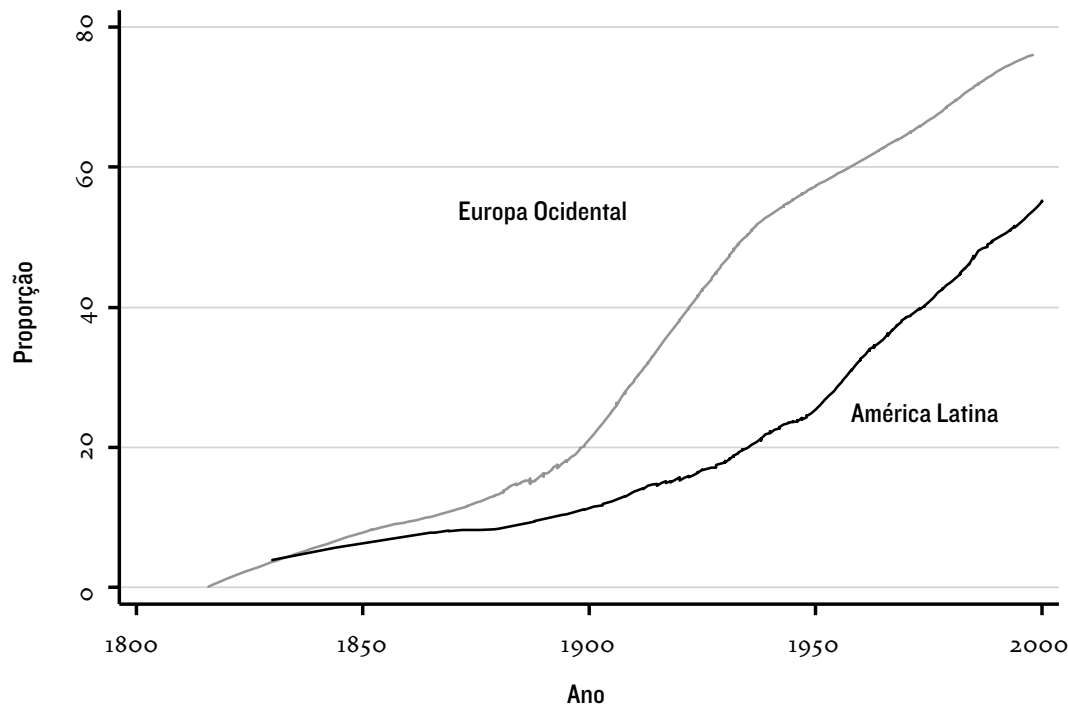

Lowess smooth. Não ponderada pelo tamanho do país.

Fonte: dados próprios.

Há que observaro seguinte no que diz respeito ao momento cronológico: as eleições ocorriam com maior frequência mais cedo na América Latina, as regras de sufrágio incluíam mais cedo homens pobres, e a proporção da população com direito de votar era mais ou menos a mesma.

Comparações quanto ao nível de desenvolvimento são difíceis, porque séries temporais de renda (de Maddison, 2003) só estão disponíveis para a América Latina basicamente depois de 1870 . No entanto, sabemos que os países latino-americanos eram mais pobres que os da Europa Ocidental já em 1820 , de modo que realizavam mais eleições com níveis mais baixos de renda.

TABELA I

Renda per capita 1700-2000

\begin{tabular}{|c|c|c|c|c|}
\hline & 1820 & 1870 & 1930 & 2000 \\
\hline Brasil & 646 & 713 & 1.048 & 5.556 \\
\hline México & 759 & 674 & 1.618 & 7.218 \\
\hline América Latina ${ }^{\mathrm{a}}$ & 701 & 756 & 1.873 & 5.844 \\
\hline EUA & 1.257 & 2.445 & 6.123 & 2.8129 \\
\hline Europa Ocidental ${ }^{b}$ & 1.196 & 1.849 & 3.974 & 1.6823 \\
\hline
\end{tabular}

Nota: a. Médias ponderadas de população em países sobre os quais existem dados disponíveis: 17 países em 1820 (excluindo Cuba e República Dominicana), Brasil, México, Argentina, Uruguai e Venezuela, em 1870,13 países em 1930, 18 em 2000. b. Média não ponderada de 12 países em 1820,14 em 1870,15 em 1930 e 19 em 2000. Fonte: Conjunto de dados em Maddison (2003: 114) e Maddison (2003). 
Dados pós-1870 mostram que a frequência na realização de eleições era quase idêntica nos dois continentes até que os países latino-americanos atingissem uma renda percapita de cerca de US $\$ 5.000^{17}$.

\section{FIGURA 4}

Proporção de países que realizavamndo eleições, por PIB per capita

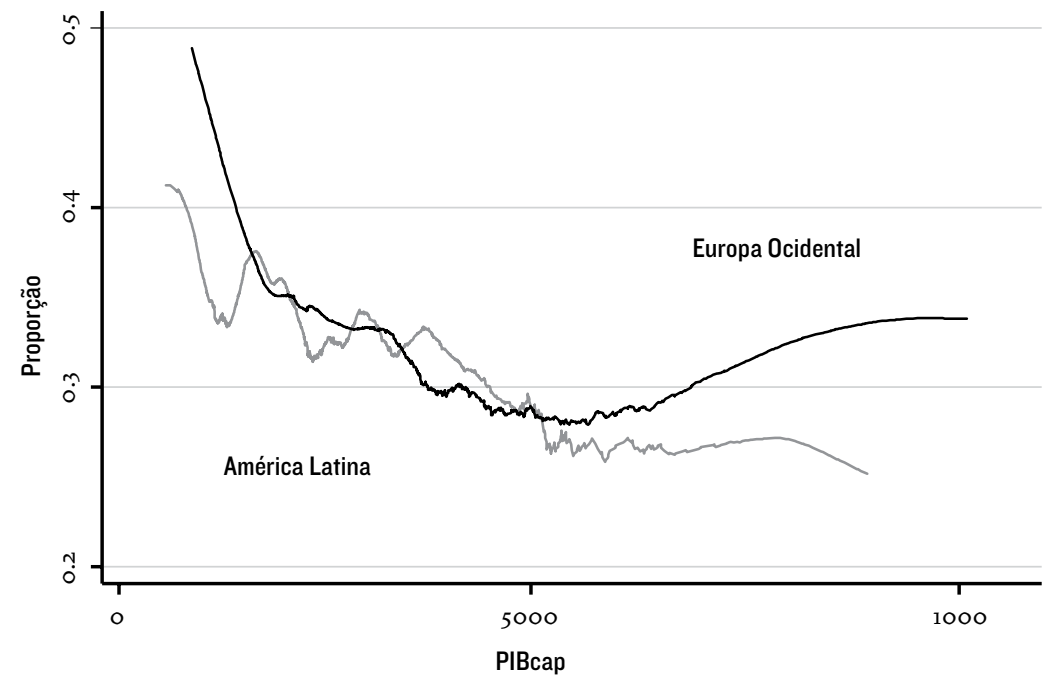

Lowess smooth. Inclui eleições legislativas e presidenciais, mas apenas uma ou outra por ano. Somente para anos > 1869 devido a informações e somente dentro do mesmo intervalo de renda Fonte: dados próprios e Maddison (2003).

\section{FIGURA 5}

Proporção da população elegível para votar, por renda per capita

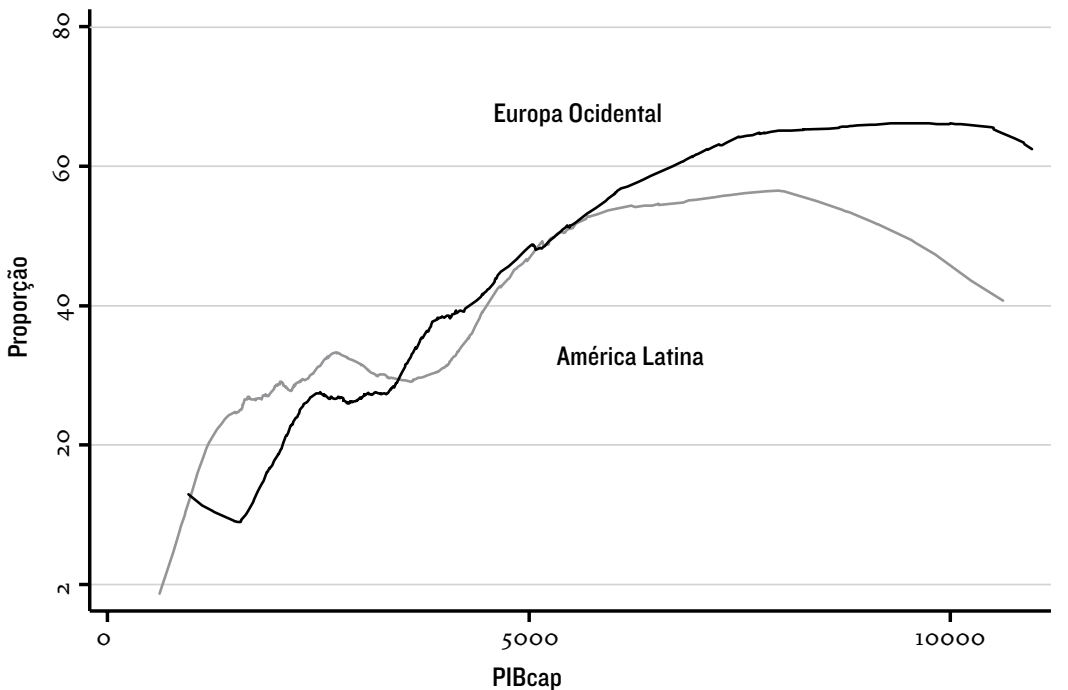

[17] Esses são dólares de 1996 conforme o método G-K de paridade de poder de compra, extraídos de Maddison (2003). Para se ter uma noção do valor de US $\$ 5.000$, essa era a renda da Costa Rica em 1979 e 1992, do México em 1974, da Argentina em 1949, do Chile em 1966 e 1982, da Colômbia em 1993 e do Uruguai em 1951 e 1973

Lowess smooth. Somente para anos $>1869$ devido a informações insuficientes e somente dentro do mesmo intervalo de renda. Fonte: dados próprios e Maddison (2003). 
[18] "República oligárquica", um termo frequente na historiografia latino-americana, não funciona neste contexto porque também precisamos incluir as monarquias da Europa Ocidental. Repare que o primeiro-ministro (ou equivalente) é considerado o chefe do Poder Executivo em tais sistemas mesmo que a Constituição determine que tal poder cabe ao rei.
A proporção de pessoas elegíveis para votar na América Latina era maior até uma renda de cerca de US $\$ 6.000$ (lembre-se de que a série da América Latina é enviesada para baixo.)

Em média, então, os países latino-americanos realizavam mais eleições e com um eleitorado mais amplo, com níveis mais baixos de renda.

\section{MECÂNICA}

Para resumir diferentes aspectos do desenvolvimento político, podemos pensar em termos de dois tipos de regime político. Em um deles, existe algum pluralismo institucionalizado: o chefe do poder executivo designado de forma constitucional é eleito, há um poder legislativo e uma oposição eleitoral ao governo em exercício é tolerada. No segundo, o poder é exercido pela força: o chefe do poder executivo não é eleito, ou governa sem um poder legislativo, ou nenhuma oposiçãoé tolerada. O primeiro regimeé uma "poliarquia". Mas Dahl (1971) usou esse rótulo em um sentido bem mais amplo. Talvez o melhor termo para identificá-lo fosse "el gobierno constitucional", mas esse termo, por sua vez, não funciona tão bem fora da tradição jurídica latino-americana ${ }^{18}$.É um sistema em que oligarquias plurais tentam processar seus conflitos utilizando regras, especificamente eleições e controle legislativo sobre orçamentos. O segundo tipo de regime talvez seja conhecido de forma menos controversa como "autocracia".

Uma vez que continuarei rotulando o primeiro sistema de "democracia", talvez seja útil refletir sobre os aspectos em que tal sistema não precisa ser a democracia conforme atualmente entendemos o termo. Um critério que ele não precisa satisfazer é o sufrágio universal, o que é enfatizado por Dahl (1971). O segundo aspecto que pode estar ausente é a possibilidade de alternância partidária no governo: vimos que durante a maior parte do século XIX era praticamente certo que os incumbentes ganhassem as eleições. Mas repare que, tal como definido, esses regimes de fato compreendem sistemas em que os direitos políticos são universais e as eleições são competitivas.

Independentemente de como esses regimes sejam rotulados, o que importa é que a América Latina tentou instituir sistemas constitucionais que previam eleições e toleravam pelo menos algum tipo de oposição com níveis de renda mais baixos que os da Europa Ocidental. A Figura 6 mostra a probabilidade de que um país tente instituir um sistema como esse com níveis específicos de renda per capita. (A diferença regional entre essas probabilidades é estatisticamente significante em o,10 sempre que não houver uma sobreposição das áreas cinzentas em torno de cada linha de regressão local.) 


\section{FIGURA 6}

Probabilidade de transição para a democracia, por renda per capita

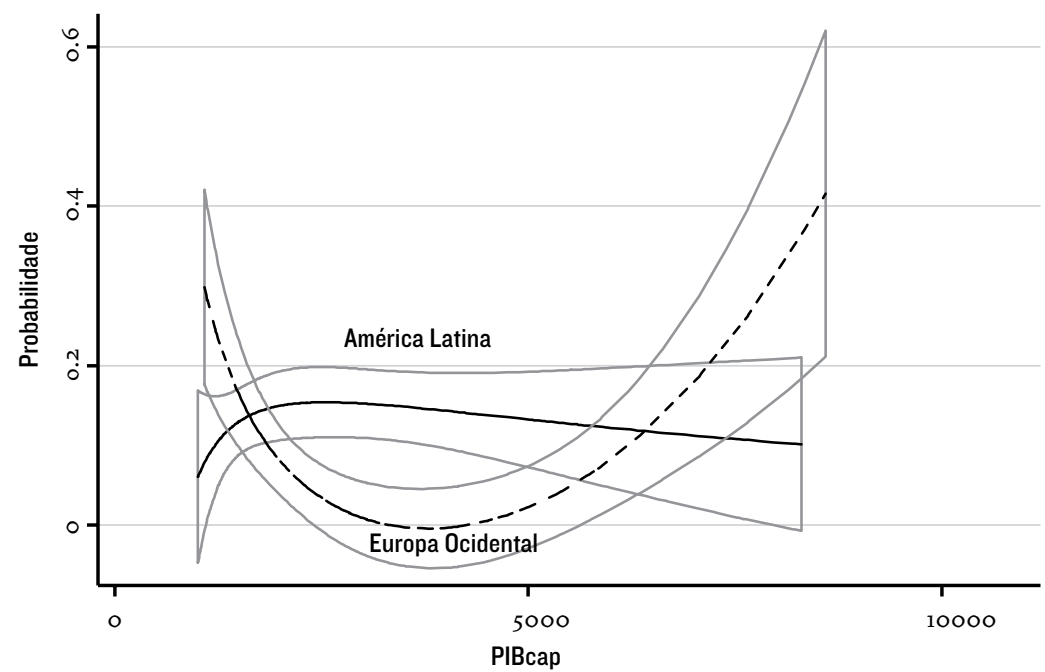

Fpift. As áreas sombreadas são intervalos de confiança de $95 \%$.

Somente para anos >1868 devido a informações insuficientes e somente dentro do mesmo intervalo de renda.

Fonte: dados próprios e Maddison (2003).

No entanto, e aqui está o enigma, as democracias foram menos frequentes na América Latina em todos os níveis de renda.

\section{FIGURA 7}

Democracias como proporção dos regimes, por renda per capita

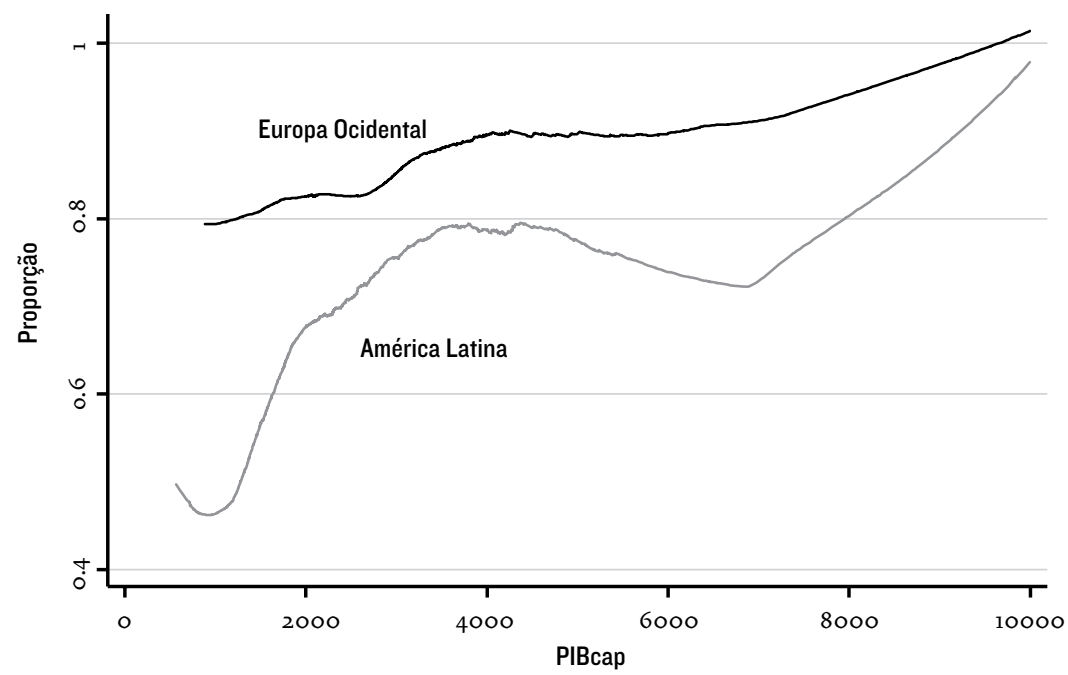

Fpift. As áreas sombreadas são intervalos de confiança de $95 \%$.

Somente para anos $>1868$ devido a informações insuficientes e somente dentro do mesmo intervalo de renda. Fonte: dados próprios e Maddison (2003).

Como é possível, então, que os países latino-americanos tenham tentado instituir democracias com níveis mais baixos de renda mas 
[19] Pense da seguinte forma: em algum momento de um passado suficientemente distante, todos os países possuíam regimes autocráticos. Alguns deles tentaram instituir uma democracia. Caso tenham tentado e fracassado, tanto a autocracia subsequente quanto qualquer futura democracia serão menos duráveis. acabaram tendo menos democracias em todos os níveis? Para explicar a diferença entre a América Latina e a Europa Ocidental, temos de introduzir dois fatos gerais: (1) a probabilidade de que, uma vez estabelecida, uma democracia sobreviva a aumentos acentuados de renda per capita, tornando-se praticamente uma certeza quando a renda é suficientemente alta, e (2) tanto a democracia quanto a autocracia são menos propensas a sobreviver se em qualquer momento no passado um país já tiver experimentado transições para a autocracia ou, o que dá no mesmo, tiver completado períodos de democracia ${ }^{19}$.

Eis a prova. A Figura 8 mostra que o que importa para uma transição para a democracia é apenas o número de visitas anteriores à democracia (stra, um mnemônico para a soma das transições para uma autocracia), e não a renda.

\section{FIGURA 8}

Probabilidade de transição para uma democracia, por PIB per capita e períodos anteriores de democracia

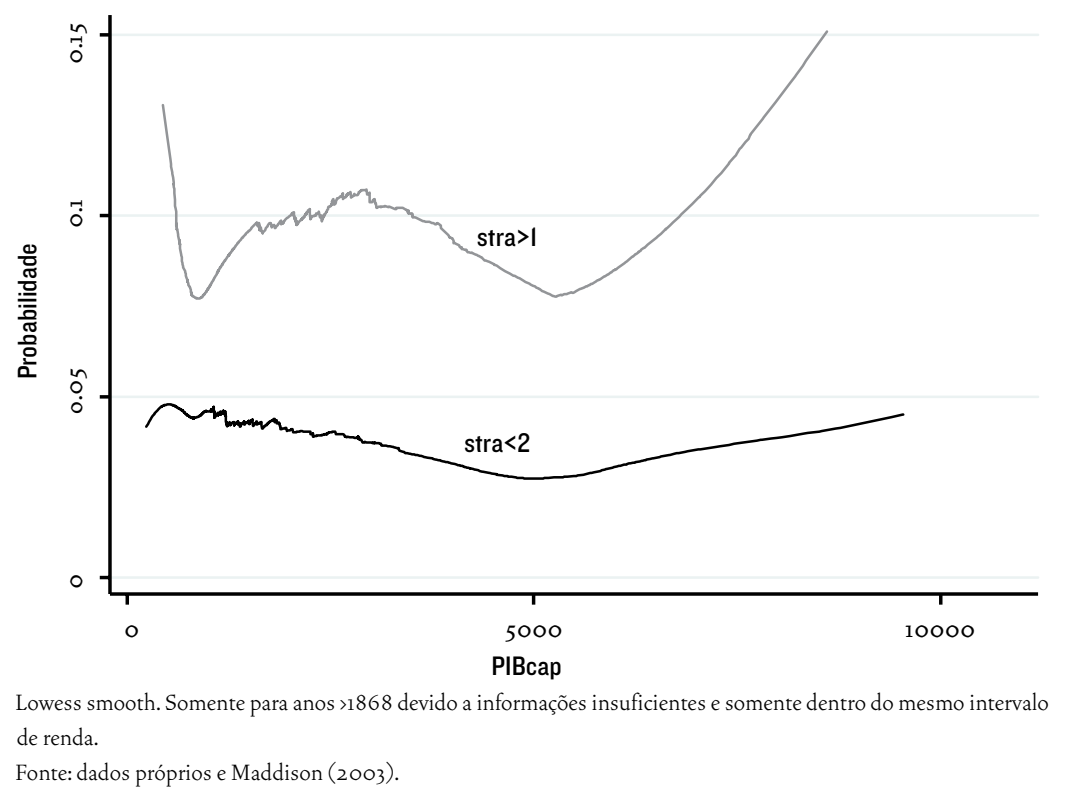

A Figura 9, por sua vez, revela que as transições para uma autocracia se tornam acentuadamente menos prováveis à medida que há um aumento de renda, mas abaixo de um determinado nível de renda são mais prováveis se um país tiver vivenciado uma democracia no passado. 
FIGURA 9

Probabilidade de transição para uma autocracia, por PIB per capita e períodos

anteriores de democracia

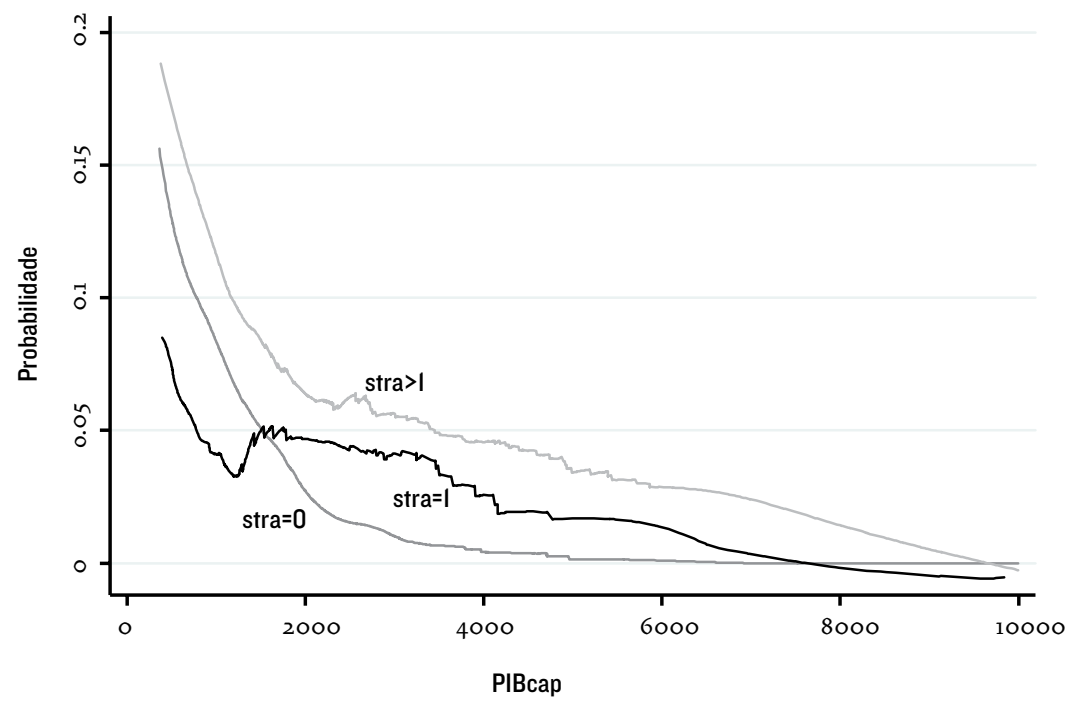

Lowess smooth. Somente para anos >1868 devido a informações insuficientes e somente dentro do mesmo intervalo de renda.

Fonte: dados próprios e Maddison (2003).

Agora, para tirar conclusões desses fatos, tomemos um país que ingresse numa democracia com um nível de renda baixo. Nesse nível, a probabilidade de que essa democracia caia é bastante elevada. Suponha que essa democracia de fato caia. A probabilidade de que a autocracia subsequente sobreviva é então menor, de modo que a probabilidade de que esse país tente novamente uma democracia é maior, mas a probabilidade de que essa segunda democracia sobreviva tambémé menor. Essa sequência pode ser repetida várias vezes, de modo que, se a renda per capita for constante, os dois regimes se tornariam cada vez mais instáveis. Mas a renda é importante: se a economia crescer no meio-tempo, a probabilidade de que uma democracia morra diminui, apesar da instabilidade do regime passado. Ehá um momento em que a renda ultrapassa um limiar acima do qual a democracia passa a ser inexpugnável, de modo que, uma vez instalada, ela dura para sempre.

Eis uma história esquemática de um país como esse, que ingressa pela primeira vez numa democracia quando tem uma renda per capita de US\$ 500; supondo que durante todo o período a renda per capita cresça a uma taxa anual de 1,63, que é a média para todo o conjunto de observações ${ }^{20}$. A probabilidade de essa democracia morrer no primeiro ano é pda = 0,1171: a expectativa de vida dessa democracia é de cerca de nove anos, ao fim dos quais o país se torna uma autocracia com uma renda de US $\$ 578$. Tendo em vista que esse país já vivenciou uma democracia uma vez, a probabilidade de que essa autocracia morra durante o primeiro ano é pad $=0,0530$, com uma expectativa
[20]A dinâmica seria mais complexa se os regimes tivessem um impacto sobre as taxas de crescimento. Especificamente, se autocracias pobres causassem uma diminuição de renda, haveria um low level trap [armadilha de baixo nível] de instabilidade crescente em ambos os regimes $\mathrm{e}$ uma renda baixa oscilante. Mas nem pesquisas anteriores nem explorações destes dados apoiam a visão de que há uma diferença sistemática entre os regimes. 
de vida de cerca de dezenove anos. O país agora novamente ingressa em uma democracia, a uma renda de US $\$ 786$, mas com o histórico de uma visita anterior à democracia. A probabilidade de que essa democracia morra é agora $p d a=0,0867<0,1171$, o que indica que o efeito do aumento da renda é maior do que o efeito de uma visita anterior à democracia. A expectativa de vida dessa democracia é de doze anos e o país reingressa na autocracia a uma renda de US $\$ 954$, com o histórico de duas visitas à democracia. Já que a renda não afeta a probabilidade de a autocracia morrer, mas visitas anteriores à democracia aumentam essa probabilidade, pad $=0,0605>0,0530$, e expectativa de vida dessa autocraciaé de dezesseis anos.AFigura 12 mostra as probabilidades de transição (para os anos em que o país ingressa em um determinado regime) e a expectativa de vida de cada regime, conforme o aumento de renda. A duração dos períodos democráticos se torna mais longa e a dos períodos autocráticos, mais curta, até que o país ingresse numa democracia com um nível de renda em que é certo que ela sobreviverá. Repare que esse país terá vivenciado onze regimes, incluindo um surto de autocracia com um nível de renda relativamente alto (em torno do nível da Argentina e do Uruguai em 1976).

FIGURA 10

A história estilizada de um país

Nota: nesta figura, pjk significa a probabilidade de transição para uma autocracia, pda, quando um país é atualmente uma democracia, e a probabilidade de transição para uma democracia, pad, quando é uma autocracia. Os regimes atuais são indicados por um $d$ quando um país é uma democracia e por um a quando se trata de uma autocracia. Os números ao lado das letras mostram a expectativa de vida desses regimes, dados a renda per capita e o número de visitas anteriores à democracia, onde a expectativa de vida é o inverso da probabilidade de transição. Este exemplo foi calibrado usando os resultados estatísticos apresentados no Apêndice.

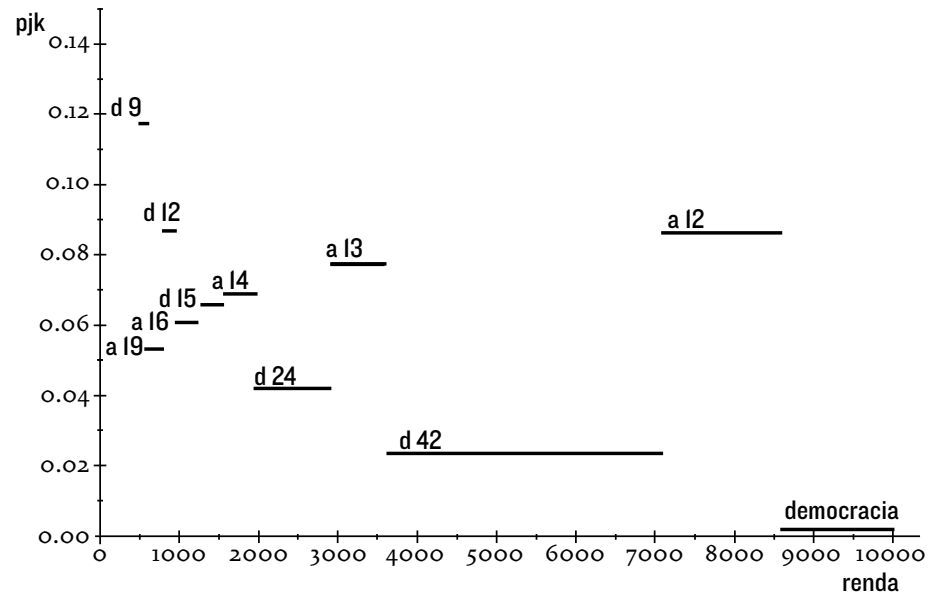

Em contraste, considere um país que ingressa pela primeira vez na democracia com uma renda de US $\$ 2.000$. Essa democracia tem uma expectativa de vida de 38 anos e o país ingressa na autocracia com uma renda de US\$3.697. Após 21 anos de autocracia, o país reingressa na democracia com uma renda de US $\$ 5.192$, quando $p d a=0,0088$ e a expectativa de vidaéde 114 anos. A não ser que haja um evento altamente improvável durante os primeiros anos dessa democracia, esse regime, portanto, dura para sempre. 
Repare que os motivos pelos quais os períodos autocráticos se tornam mais curtos e os democráticos mais longos com rendas mais elevadas são diferentes. Períodos autocráticos são mais curtos quase exclusivamente porque os países com renda mais elevada acumularam mais visitas à democracia, e essas visitas desestabilizam os períodos autocráticos subsequentes ${ }^{21}$. Os períodos democráticos são mais longos, no entanto, só porque democracias duram mais tempo com níveis de renda mais altos. Embora visitas anteriores à democracia de fato desestabilizem regimes democráticos posteriores, esse efeito é pequeno, enquanto o efeito da renda é poderoso.

Para ver isso em termos agregados, suponha que numa região metade dos países ingressa na democracia pela primeira vez com uma renda per capita de US $\$ 500$, enquanto na segunda região metade dos países experimenta a democracia pela primeira vez com uma renda per capita de US\$ 1.500. A Figura 11 mostra a proporção de democracias nas duas regiões ao longo do tempo.

\section{FIGURA II}

Probabilidade de democracia por anos desde o primeiro ingresso e pelo nível de renda no primeiro ingresso

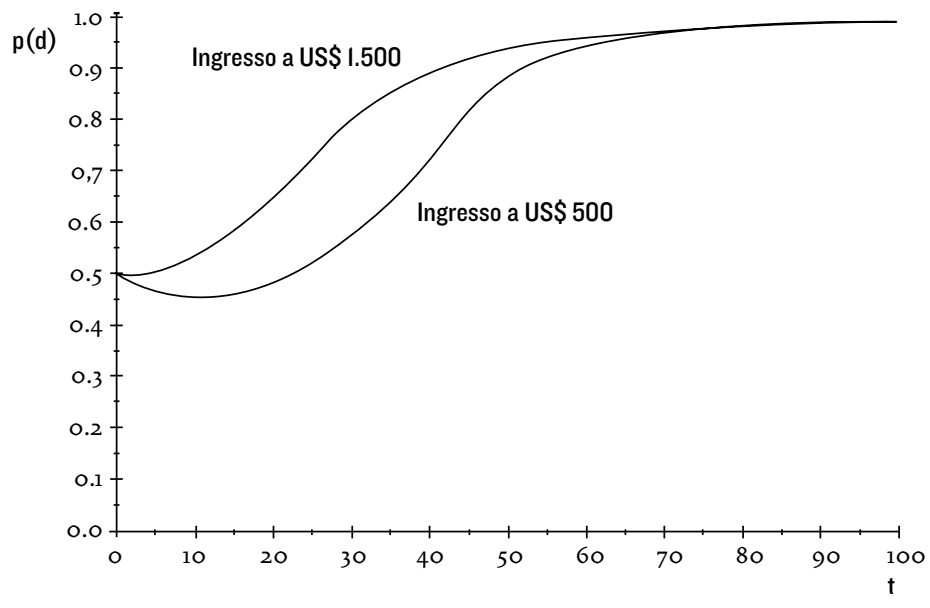

Assim, o enigma é elucidado. Os países que experimentam a democracia abaixo de certo nível de renda têm pouca probabilidade de sustentá-la. Portanto, tornam-se autocracias, enquanto os países que adotaram a democracia com níveis de renda mais altos continuam como democracias. Experiências passadas com a democracia desestabilizam ambos os regimes. Porém, embora os países que adotam a democracia quando são mais pobres vivenciem maior instabilidade de regime, à medida que sua renda aumenta, cada democracia subsequente é mais durável. No fim, independentemente dos níveis de renda iniciais, quando sua renda se torna suficientemente alta, todos os países atingem uma situação em que a democracia dura para sempre.
[21] Já que rendas mais elevadas mascaram experiências passadas de democracia, vários pesquisadores erroneamente atribuem a vida mais curta de autocracias em países mais ricos à renda. Ver, por exemplo, Boix e Stokes (2003).

Nota: $p(d)$ é a proporção de países que são democráticos em cada momento (supondo que a renda aumente a uma taxa constante e o número de visitas anteriores à democracia esteja no valor médio). 
[22] Tecnicamente, a função de utilidade é côncava em quaisquer argumentos que possam ser afetados ao se rebelar.
Como essas intuições não são nem um pouco óbvias, o argumento é desenvolvido formalmente no Apêndice.

\section{EXPLICAÇÕES}

A dinâmica dos regimes é impulsionada por dois mecanismos: a probabilidade de uma democracia morrer diminui com o aumento da renda per capita e visitas anteriores à democracia desestabilizam ambos os regimes, especialmente as autocracias.

Uma explicação para o fato de que a estabilidade democrática depende da renda é a seguinte. Pense na democracia, e mais estritamente nas eleições, como um método para processar conflitos de acordo com regras. Os grupos politicamente relevantes - aqueles com alguma capacidade de mobilização de forças - podem respeitar os resultados decorrentes da aplicação das regras, de novo mais estritamente o resultado de uma eleição, ou se rebelar, correndo o risco de ser derrotados pela força. Agora, suponha que, quando as pessoas gozam de uma renda mais elevada, elas se importam menos com o que poderiam ganhar pelo uso da força ${ }^{22}$, mas se preocupam tanto quanto as pessoas mais pobres com como evitar a violência. Isso é o suficiente para gerar a conclusão de que, acima de certo nível de renda, que talvez seja diferenteem diferentes sociedades, o ganho potencial de se rebelar contra resultados gerados por regras é menos valorizado que o risco de violência. Quando isso é verdade para todos os grupos politicamente relevantes, a democracia sobrevive.

Essa explicação é obviamente esquemática e incompleta, mas ela pode ser substanciada de várias maneiras. Além disso, sejam quais forem os detalhes que se possam acrescentar, a intuição básica permanece (ver Przeworski, 2005; Benhabib e Przeworski, 2006; Przeworski, 2006). É por isso também que os resultados aqui apresentados não são sensíveis a definições de democracia. Contanto que a própria possibilidade de conflitos de interesses ou valores seja admitida, permitindo até mesmo um mínimo de oposição, os conflitos devem ser processados de acordo com algumas regras, por mais que essas regras sejam tendenciosas em favor dos detentores de poder na época em questão. E, enquanto houver regras, as forças políticas - tanto as que estão no poder quanto as que estão fora do poder - terão de decidir repetidas vezes se devem ou não aceitar os resultados gerados pela aplicação dessas regras. De fato, reproduzi algumas das análises que codificam como democracias somente os regimes em que os chefes do Poder Executivo entraram e saíram do cargo de acordo com normas constitucionais previamente estabelecidas e, ainda mais estritamente, somente os regimes em que os governos incumbentes foram às vezes derrotados nas urnas e deixaram o cargo de forma pacífica. Todos os 
padrões descritos aqui se confirmaram para essas definições de democracia sucessivamente mais estreitas.

O que eu acho mais intrigante é o porquê de ambos os regimes serem menos duráveis quando eles ocorrem após experiências fracassadas de democracia. $\mathrm{Na}$ medida em que tal efeito diz respeito a autocracias, é possível invocar "tradições democráticas": se um país vivenciou uma democracia (ou várias democracias), eleé mais propenso a procurá-la novamente. Essa linha de pensamento foi influenteem alguns estudos de transições para a democracia: o Chile,com sua longa tradição democrática, foi considerado mais disposto a restaurar uma democracia do que, digamos, a Argentina. Mas o fato de que democracias subsequentes a tentativas passadas fracassadas também são menos duráveis, mesmo que o efeito numérico seja menor e no fim dominado pela renda, põe em dúvida a primeira explicação. Se existe um aprendizado político, este parece se aplicar a ambos os casos: sob uma autocracia as pessoas se lembram da democracia, mas sob a democracia elas sabem por experiência que e como ela pode ser derrubada ${ }^{23}$.

Uma explicação mais plausível tem a ver com o papel dos militares. Para considerar esse papel, é preciso fazer um desvio. Uma hipótese concorrente com a mecânica proposta aqui seria que a instabilidade de regime na América Latina se deve ao fato de que todas as democracias latino-americanas foram presidenciais, e o presidencialismo torna uma democracia mais frágil. No entanto, Cheibub (2007) refutou essa explicação de maneira decisiva, observando que a diferença entre a longevidade das democracias parlamentares e presidenciais desaparece quando consideramos se a ditadura anterior à democracia atual era civil ou militar. No fim, Cheibub (2007: 140) conclui, "o que mata as democracias não é o presidencialismo, mas seu legado militar". Por sua vez, Przeworski (2004), usando uma definição de democracia um pouco mais restrita, descobriu que todas as ditaduras em países que tiveram mais de uma visita anterior à democracia eram militares. Finalmente, há uma literatura extensa documentando que os militares frequentemente assumem o poder com a missão transitória de "restabelecer a ordem" e se recolhem de volta aos quartéis depois de matar um número suficiente de pessoas (Finer, 1976; Nordlinger, 1977; Permlutter, 1977). Por isso, visitas anteriores à democracia podem encurtar a vida de regimes posteriores, porque, por um lado, as democracias seguintes a ditaduras militares duram menos, enquanto, por outro lado, as ditaduras seguintes a períodos completos de democracia tendem a ser militares, e ditaduras militares também duram menos.

Embora sejam muito úteis, esses dois mecanismos não são suficientes para explicar por completo a diferença entre a longevidade da democracia na Europa Ocidental e na América Latina. Nem tudo é mecânico. A súbita erupção de instabilidade política em meados da década de 1920, tanto na Europa quanto na América Latina ${ }^{24}$,
[23] Basta lembrar como os golpistas russos de agosto de 1991 foram amadores: eles não cortaram as linhas telefônicas, não introduziram um toque de recolher, e nem sequer prepararam uma declaração do novo governo. Seus experientes irmãos do peito latino-americanos devem ter zombado deles com desprezo.

\footnotetext{
[24] De acordo com Rouquie (1994: 223), "Entre fevereiro e dezembro de 1930 , os militares estiveram envolvidos na derrubada de governos em nada menos do que seis países latino-americanos bastante diferentes - Argentina, Brasil, República Dominicana, Bolívia, Peru e Guatemala. No mesmo ano também houve quatro tentativas infrutíferas de tomada de poder pela força em outros países latino-americanos. Ao longo dos anos seguintes, o Equador e El Salvador, em 1931, e o Chile, em 1932, entraram para a lista de países em que o poder executivo sofreu alterações políticas e mudanças não programadas provocadas por militares".
} 
na maioria dos países esteve associada a crises econômicas, mas as consequentes reduções de renda não foram grandes o suficiente para afetar de maneira significativa a probabilidade de sobrevivência das democracias. Assim, esse colapso contemporâneo generalizado das democracias em diferentes partes do mundo requer uma análise separada. Talvez, como Weyland (2008) argumentou em relação à onda revolucionária de 1848 , a difusão tenha desempenhado um papel independente das condições locais. Por sua vez, embora em ambos os continentes a democracia tenha se tornado de novo mais frequente depois de 1946, a Grécia foi o único país da Europa Ocidental em que ela posteriormente entrou em colapso, enquanto na América Latina não houve uma única democracia existente em 1946 que tenha sobrevivido. Ainda que a diferença de renda per capita explique parte desse contraste, os diferentes destinos da democracia nos dois continentes provavelmente se devem, em certa medida, ao resultado da guerra. A Segunda Guerra Mundial resultou na derrota das forças autoritárias na Europa Ocidental, deixando-as intactas na América Latina, o que também significa que, na sua luta contra o comunismo, os Estados Unidos foram obrigados a buscar alianças com as forças políticas centristas na Europa, ao mesmo tempo em que podiam contar, e de fato contaram, com a extrema direita na América Latina (Cheibub, 2007).

FIGURA 12

Democracias como proporção dos regimes, por ano

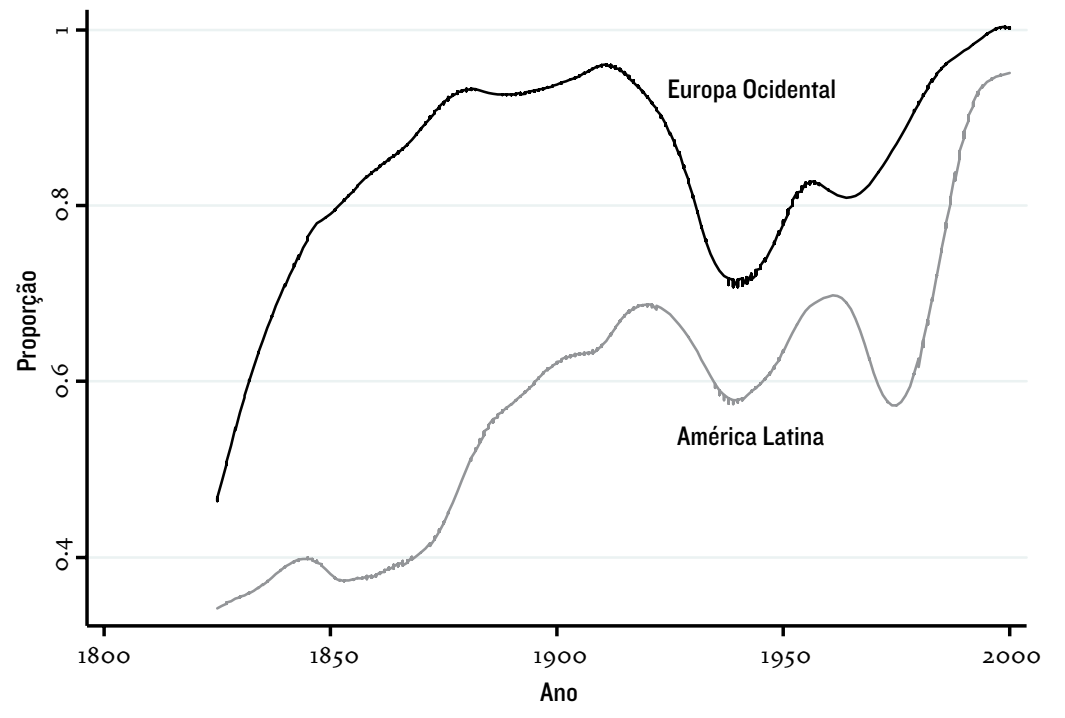

Lowess smooth. Fonte: dados próprios.

Em suma, eis a história da dinâmica dos regimes na América Latina. Os países latino-americanos surgiram como consequência de revoluções contra o domínio colonial, enquanto os países europeus vivenciaram uma devolução gradual do poder dos monarcas para os 
parlamentos. Como resultado, os países latino-americanos tentaram introduzir instituições representativas com níveis mais baixos de renda do que os europeus. Como essas instituições são menos estáveis com níveis de baixa renda e já que experiências passadas com a democracia desestabilizam regimes, as instituições representativas se alternaram intermitentemente com a autocracia. Somente quando a renda se tornou suficientemente alta é que a democracia se tornou mais estável na América Latina. Mas esses padrões gerais não contam toda a história: 0 colapso generalizado das democracias em ambos os continentes durante o período entre as guerras permanece intrigante, enquanto a instabilidade da democracia na América Latina depois da Segunda Guerra Mundial se deveu à sobrevivência das forças autoritárias nesse continente.

\section{ANEXO}

\subsection{Análise}

Sejam $j \in\{a, d\}$ oíndice de regime, $\operatorname{Pr}\{$ opaís item regime $j e m t\}=p j(t)$, $\operatorname{Pr}\{$ o país i teve regime $k$ em $t+d t$, dado o regime jem $t\}=p j k(t)$. O processo dos regimes poderá então ser escrito como ${ }^{25}$

$$
\begin{aligned}
& \dot{p}_{d}(t)=-p_{d a}(t) p_{d}(t)+p_{a d}(t) p_{a}(t) \\
& \dot{p}_{a}(t)=p_{d a}(t) p_{d}(t)-p_{a d}(t) p_{a}(t)
\end{aligned}
$$

Usando o fato de que $p a=1-p d$, a equação que rege a dinâmica das democracias pode ser reescrita como

$$
p d(t)=-[p d a(t)+p a d(t)] p d(t)+p a d(t) .
$$

Assim, a partir de qualquer condição inicial, $p d(t)$ converge para a trajetória $p^{*} d(t)$, dada por

$$
p^{*} d(t)=\frac{\operatorname{pad}(t)}{\operatorname{pad}(t)+\operatorname{pda}(t)} .
$$

Agora, considere o comportamento de $p^{*} d(t)$ como uma função da renda per capita, $y(t)$, e o número de visitas anteriores à democracia, $s(t)$ ("visitas anteriores" são períodos completos de democracia, isto é, casos em que um país teve um regime democrático que morreu em qualquer momento no passado). Suponha que $p d a=F(y, s), p a d=G(y$, s), $\operatorname{com} \partial F / \partial y<0, \Delta \mathrm{F} / \Delta \mathrm{s}>0, \lim _{y \rightarrow y^{*}(s)} F(y, s)=0, e \Delta G / \Delta s>0$. Essas premissas dizem que a probabilidade de uma transição para a autocracia diminui com o aumento da renda per capita e aumenta com o número de visitas anteriores à democracia, tendendo a o à medida que
[25] Os pontos representam derivados temporais. Escrever o processo em termos contínuos é mais conveniente porque evita algumas complicações artificiais que surgem quando o tempo é tratado de forma discreta. Repare, no entanto, que os dados são anuais. 
a renda atinge um valor mínimo $y^{*}(s)$ que depende de s. Por sua vez, a probabilidade de transição para uma democracia aumenta com o aumento do número de democracias anteriores. Já que essa questão é controversa, por enquanto deixo em aberto o sinal de $\partial G / \partial y$, o impacto da renda sobre a probabilidade de transição para uma democracia.

Reescrever (2) explicitamente em termos dey es gera

$$
p^{*} d(y, s)=\frac{\operatorname{pad}(s, y)}{\operatorname{pad}(s, y)+\operatorname{pda}(s, y)} .
$$

Observe primeiramente que, à medida que y se torna grande e pda tende a $o, p^{\star} d$ tende a 1 para todos os valores para $p a d(s, y)$. Por sua vez, mesmo que pad aumentasse em renda, a menos que pda( $y)$ tenda a $\mathrm{O}, \mathrm{a}$ probabilidade de que um país seja democrático seria inferior a 1 mesmo com níveis de renda muito altos, o que é incompatível com o fato observado de que todos os países ricos (não petrolíferos) têm regime democrático. Assim, a condição $\lim _{y \rightarrow y^{*}(s)} p d a(y, s)=0$ é necessária para que $p^{*} d(y)$ tenda à certeza. E também é suficiente: mesmo que pad seja independente dey es, $p^{*} d(y) \rightarrow 1$ desde que $p d a(y, s) \rightarrow 0$.

Para estudar a dinâmica desse processo, use $p^{*} d(t) \mathrm{em}(1)$

$$
p d(t)=[p d a(t)+\operatorname{pad}(t)]\left[p^{*} d(t)-p d(t)\right]
$$

Considere agora o efeito das condições iniciais $p d(0), y(0)$ es $(0)=0$, ou seja, quando os países experimentam a democracia pela primeiravez. Se um país tenta uma democracia com uma renda baixa, $p^{*} d(\gamma(0), 0)$ é baixo, $\operatorname{esep}^{*} d(0)<p d(0)$, a probabilidade de uma democracia diminui. Com o aumento da renda ao longo do tempo, no entanto, $p^{*} d(y, 0)$ aumenta. Porisso, deve haver algum tempo $T$ tal que $p d(t \geq T)=p^{*} d(t \geq T)$.

FIGURA IIB

Probabilidade de uma democracia e o caminho de equilíbrio por anos desde 0 primeiro ingresso e pelo nível de renda no primeiro ingresso

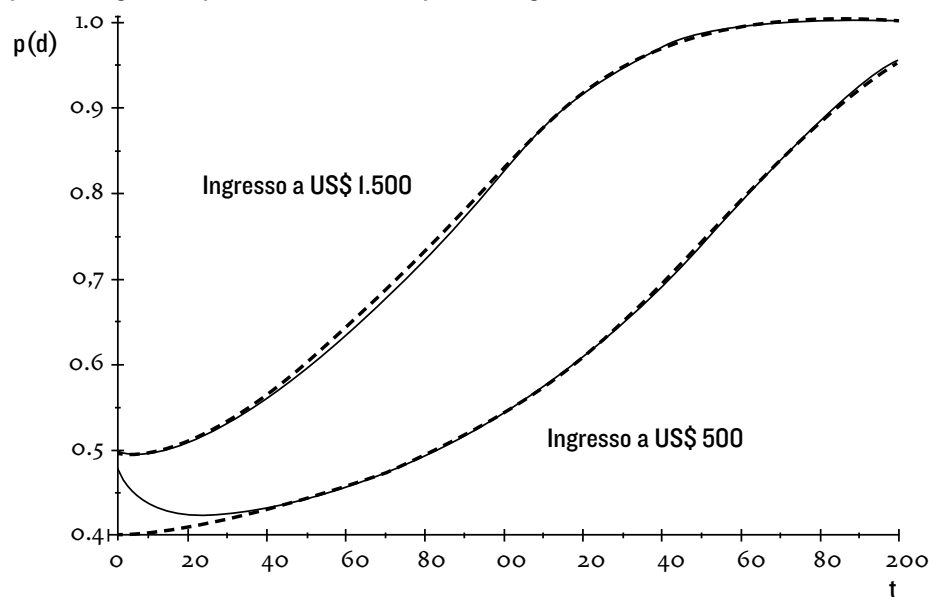


Para uma melhor percepção, considere uma versão da Figura 11 aumentada pelas trajetórias temporais $\operatorname{de} p^{*}(t)$. Um país que ingressa na democracia $\operatorname{com} y(0)=500$ epd $(0)=0,5>p^{*}(0) \approx 0,42$ verá a probabilidade de democracia diminuir por cerca de $T=30$ anos (supondo que durante esse tempo a renda cresça a uma taxa constante de 1,63 por ano), ao passo que um país que ingressa com a mesma probabilidade $\operatorname{com} y(0)=1.500$ terá $p^{*}(0)>0,5$, de modo que sua probabilidade de democracia continuará a aumentar.

Visitas anteriores à democracia afetam o ritmo do processo, mas não seu destino final. Quando uma democracia cai, de modo ques aumenta em 1,pad aumenta, assim como o valor de $p^{*}$. Assim, a dinâmica de transição descrita na equação (3) é acelerada e a proporção de democracias converge mais rapidamente para o limite. Visitas anteriores à democracia, por sua vez, também aumentam o valor de pda, e esse aumento retarda a convergência. No longo prazo, no entanto, todos os países se tornam democráticos independentemente da instabilidade de regimes anteriores.

Finalmente, repare que, mesmo que pad seja independente da renda, uma análise estatística que ignore as visitas anteriores mostrará uma correlação positiva entre essa probabilidade e renda. Isso ocorre porque, no momento em que um país tenha acumulado uma renda mais alta, é mais provável que ele também tenha acumulado visitas anteriores, de modo que $E_{t}(s)=s(\gamma(t))$. Portanto,

$$
\frac{d p a d}{d y}=\frac{\partial_{p a d}}{\partial y}+\frac{\partial_{p a d}}{\partial s} \frac{d s}{d y} .
$$

Porque $\frac{\partial p a d}{\partial y}>0 e \frac{d s}{d y}>0, \frac{d p a d}{d y}>0$ mesmo quando $\frac{\partial p_{a d}}{\partial y}=0$.

Um volume considerável de literatura (Boix e Stokes, 2003; Epstein et al., 2003) se baseia nessa falácia.

\subsection{Estatísticas}

Os dados são provenientes do PACKT (2008). Eles cobrem, embora com hiatos e lacunas, vários aspectos das instituições políticas e dos eventos no mundo, começando em 1788 .

"Democracia" foi codificada como um regime em que o chefe do Poder Executivo é eleito, a legislatura está em funcionamento e pelo menos algum tipo de oposição é permitido por lei. $O$ chefe do poder executivo é um presidente se não houver primeiro-ministro; senão, é um primeiro-ministro. Um poder legislativo é um órgão que não exerce uma função executiva e tem algum controle sobre os impostos. A oposição existe se pelo menos em alguns distritos os eleitores po- 
dem exercer uma escolha partidária (operacionalmente, foi codificada como existente se havia mais de um partido no legislativo ou mais de um candidato em eleições presidenciais). Regimes que não apresentam pelo menos uma dessas condições foram codificados como "autocracias".

Abaixo estão os resultados de regressões probit para pad e pda.

TABELA AI

Regressão probit. Variável dependente: $p d a . \mathrm{N}=5067$

\begin{tabular}{|c|c|c|c|c|}
\hline & Coeficiente & s.e. & $z$ & $\operatorname{Pr}(z)$ \\
\hline log PIBcap & $-0,5527$ & 0,0602 & $-9,18$ & 0,000 \\
\hline stra & 0,0696 & 0,0143 & 4,85 & 0,000 \\
\hline constante & 2,2655 & 0,4302 & 5,27 & 0,000 \\
\hline
\end{tabular}

Nota: os erros-padrão estão agrupados por país.

TABELA A2

Regressão probit. Variável dependente: pad. N=3006

\begin{tabular}{|c|c|c|c|c|}
\hline & Coeficiente & s.e. & z & $\operatorname{Pr}(\mathrm{z})$ \\
\hline $\log$ PIBcap & $-0,0345$ & 0,0555 & $-0,62$ & 0,534 \\
\hline stra & 0,0818 & 0,0126 & 6,47 & 0,000 \\
\hline constante & $-1,4780$ & 0,4038 & $-3,66$ & 0,000 \\
\hline
\end{tabular}

Nota: os erros-padrão estão agrupados por país.

\section{REFERÊNCIAS BIBLIOGRÁFICAS}

Aguilar Rivera, José Antonio. En pos de la quimera: reflexiones sobre el experimento constitucional atlântico. México: CIDE, 2000.

Annino, Antonio. "Introducción". In: Antonio Annino (ed.).Historia de las elecciones en Iberoamérica:siglo XIX. México: Fondo de Cultura Económica, 1995.

. "Vote et décalage de la citoyenneté dans les pays andins et meso-americains". In: R. Romanelli (ed.). How did they become voters? The history of franchise in modern European representation. Haia: Kluwer, 1998, pp.155-82.

Bahamonde, Ángel e Martínez, Jesús A. Historia de España:siglo XIX. Madri: Catedra, 1998.

Benhabib, Jess e Przeworski, Adam. "The political economy of redistribution underdemocracy. Economic Theory, 29, 2006, pp.271-290. 
Birmingham, David. A concise history of Portugal. Cambridge: Cambridge University Press, 1993.

Boix, Carles e Stokes, Susan. "Endogenous democratization. WorId Politics, 55, 2003, pp. 517-49.

Bolívar, Simón. Escritos políticos. Editado por Graciela Soriano. Madri:Alianza Editorial, 1969.

Bushnell, David.The making of modern Colombia. Berkeley: University of California Press, 1993.

Canedo, Leticia Bicalho. "Les listes électorales el le processus de nationalisation de la cityoennetè au Brésil (1822-1945)". In: Raffaele Romanelli (ed.). How did they become voters? The history of franchise in modern European representation. Haia: Kluwer, 1998, pp.183-206.

Cheibub,JoséAntonio.Presidentialism, parliamentarism, and democracy. Nova York: Cambridge University Press, 2007.

Collier, Simone Sater, William F. A history of Chile,1808-1994.Cambridge: Cambridge University Press, 1996.

Crook, Malcolm. Elections in the French Revolution. Cambridge:Cambridge University Press, 1996.

Dahl, Robert A. Polyarchy:participation and opposition. New Haven: Yale University Press, 1971.

Dardé, Carlos e Estrada, Manuel. "Social and territorial representation in Spanish electoral systems". In: Raffaele Romanelli (ed.).How did they become voters? The history of franchise in modern European representation. Haia: Kluwer, 1998, pp.133-154.

De Luca, Miguel. "Los ejecutivos". In: Hipólito Orlandi (ed.). Las instituciones politicas de gobierno (vol.I, pp. 89-132). Buenos Aires: Editorial Universitaria, 1988.

Dunn, Susan. Jefferson's second revolution: the election crisis of 1800 and the triumph of republicanism. Boston: Houghton Mifflin, 2004.

Epstein, David L.; Bates, Robert; Goldstone, Jack; Kristensen, Ida; O'Halloran, Sharyn. Democratic transitions. Texto preparado para apresentação na Annual Meeting of the Midwest Political ScienceAssociation, Chicago, 3-6 de abril, 2003.

Finer, Samuel. The man on horseback: the role of the military in politics. 2.ed. Harmondswoth: Penguin, 1976.

Gargarella, Roberto.Losfundamentoslegales de la desigualidad:el constitucionalismo en América (1776-1860). Madri: Siglo XXI, 2005.

Garrido, Aurora. "Electors and electoral districts in Spain, 18741936". In: Raffaele Romanelli (ed.). How did they become voters? The history of franchise in modern European representation. Haia: Kluwer, 1998, pp. $207-226$.

Guerra, François-Xavier. "El soberano y su reino: reflexiones sobre la génesis del ciudadano en América Latina". In: Hilda Sabato (ed.), Ciudadanía política y formación de las naciones: perspectivas 
históricas de América Latina. Mexico: El Colegio de Mexico, 2003, pp.33-61.

Halperin-Donghi, Tulio. The aftermath of revolution in Latin America. Nova York: Harper\&Row, 1973.

Hansen, Mogens Herman. The tradition of democracy from antiquity to the present time. Texto apresentado no Seminar on Democracy:Ancient and Modern. Roma: Fondazione Adriano Olivetti, 2005.

Haring, Clarence Henry. The Spanish empire in America. Nova York: Harcourt, Brace\&World, 1947.

Hofstadter, Richard. The idea of the party system: the rise of legitimate opposition in the United States, 1780-1840. Berkeley: University of California Press, 1969.

Klinghofer, Judith Apter e Elkis, Lois. "The petticoat electors: women's suffrage in New Jersey, 1776-1807". Journal of the Early Republic, 12, 1992, pp.159-193.

Lehoucq, Fabrice. "Can parties police themselves? Electoral governance and democratization". International Political Science Review, 23, 1, 2002, pp. 29-46.

Lehoucq, Fabrice. "Quees el fraude electoral? Su naturaleza, sus causas y consecuencias". Revista Mexicana de Sociologia, 69, 2007, pp. 1-38.

Lehoucq, Fabrice e Molina, Iván. Stuffing the ballot box:fraud, electoral reform, and democratization in Costa Rica. Nova York: Cambridge University Press, 2002.

Levitsky, Steven e Way, Lucan A. "The rise of competitive authoritarianism". Journal of Democracy, 13, 2, 2002, pp. 51-65.

Lipset, Seymour Martin. Political man: the social bases of politics. Garden City: Doubleday, 1960.

López-Alves, Fernando. State formation and democracy in LatinAmerica,1810-1900. Durham: Duke University Press, 2000.

Loveman, Brian. The constitution of tyranny: regimes of exception in Spanish America. Pittsburgh: Pittsburgh University Press, 1993.

Maddison, Angus. The world economy: historical statistics. Paris: OECD, 2003.

Manin, Bernard. The principles of representative government. Cambridge: Cambridge University Press, 1997.

Nordlinger, Eric. Soldiers in politics:military coups and governments. Englewood Cliffs: Prentice Hall, 1977.

Palacios, Guillermo e Moraga, Fabio.La independenciay el comienzo de los regímenes representativos. Madri: EditorialSíntesis, 2003.

Paz, Octavio. "A democracia e a América Latina". Caderno de Cultura de O Estado de S. Paulo, 2, 128, 1963,pp.1-12.

Permlutter, Amos. The military and politics in modern times: on professionals, pretorians, and revolutionary soldiers. New Haven: Yale University Press, 1977. 
Posada-Carbó, Eduardo. "Electoral juggling: a comparative history of the corruption of suffrage in Latin America, 1830-1930". Journal of LatinAmerican Studies, 32,2000,pp.611-644.

Przeworski, Adam. "Democracy as an equilibrium". Public Choice, 123, 2005, pp. 253-273.

. "Self-enforcing democracy". In: Donald Wittman e BarryWeingast (eds.).Oxford Handbook of Political Economy. Nova York: Oxford University Press, 2006.

. "Constrains and choices: a history of electoral participation". Comparative Political Studies, 42, 2009, pp.4-30.

Przeworski, Adam e Curvale, Carolina. "Does politics explain the economic gap between the United States and Latin America?". In: Francis Fukuyama (ed.). La brecha entre América Latina y los Estados Unidos. Buenos Aires: Fondo de Cultura Económica, 2006.

Rippy, Fred J. "Monarchy or republic?”. In: Hugh M. Hamil, Jr. (ed.).Dictatorship in SpanishAmerica. Nova York:Alfred A. Knopf, 1965, pp. 86-94.

Rouquie Alain. "The military in Latin American politics since 1930". In: Leslie Bethell (ed.). The Cambridge History of Latin America, volume VI, parte 2: 1930 to the present. Cambridge: Cambridge University Press, 1994, pp. 233-306.

Sabato, Hilda. "Introducción". In: Hilda Sabato (ed.). Ciudadanía política y formación de las naciones: perspectivas históricas de América Latina. Mexico: El Colegio de Mexico, 2003, pp.11-29.

Valenzuela, Samuel J.The origins and transformation of the Chilean party system. Working Paper $n^{\circ} 215$. The Helen Kellogg Institute for International Studies, University of Notre Dame, 1995.

Weisberger, Bernard A.America afire:Jefferson, Adams, and the first contested election. Nova York: HarperCollins Publishers, 2000.

Weyland, Kurt. The diffusion of revolutions: 1848 in Europe and Latin America. Working Paper, Department of Political Science, University of Texas at Austin, 2008.

Zeldin, Theodore. The political system of Napoleon III. Nova York: W.W. Norton, 1958.

\begin{tabular}{l}
\hline Recebido para publicação \\
em 20 de outubro de 2014. \\
\hline NOVOS ESTUDOS \\
CEBRAP \\
100, novembro 2014 \\
pp. $27-54$ \\
\hline
\end{tabular}

